\title{
Strategies for the competitiveness of the trade in Tecamachalco, Puebla: Case of the grocery stores
}

\author{
Strategies for the competitiveness of the trade in Tecamachalco, Puebla: Case of the \\ grocery stores
}

\author{
REZA-SALGADO, Juventino $\dagger$, GUERRERO-PAPAQUI, Roxana* and LÓPEZ-GONZÁLEZ, Patricia \\ Universidad Tecnológica de Tecamachalco
}

ID $1^{\text {st }}$ Author: Juventino, Reza-Salgado / ORC ID: 0000-0001-9052-6855

ID $1^{\text {st }}$ Coauthor: Roxana, Guerrero-Papaqui / ORC ID: 0000-0003-3684-0178

ID $2^{\text {nd }}$ Coauthor: Patricia, López-González

DOI: $10.35429 / J B D S .2019 .16 .5 .27 .34$

Received July 15, 2019; Accepted December 30, 2019

\begin{abstract}
The objective was to design strategies and generate an action plan that would contribute to the competitiveness of the commercial establishments of the Tecamachalco municipality, Puebla. The procedures performed were: the review of descriptive and explanatory documentation for the identification of variables that were integrated to the survey, data processing and construction of indexes, tables and graphs to analyze and interpret the relationships between variables and generation of strategies. The results indicate that, concerning the management of the businesses, $63 \%$ never define their organizational philosophy, more than half of them never apply total quality and continuous improvement programs, 56\% never associate to supply and distribute their products and do not resort to external financing, $66 \%$ consider that the price of their product is adequate to their competitors and $64 \%$ set prices based on their level of costs and profits, and 64\% do not use accounting and management techniques but are willing to receive advice. Concerning employees, $56 \%$ of them have elementary notions of the functions and activities they perform, $67 \%$ have occasionally received incentives for the fulfillment of objectives. The strategies designed were: training in business culture with procedures, practices and standards that contribute to quality in the marketing and service processes; integrating organizations that facilitate obtaining financing for the consolidation of existing businesses; creating strategic alliances with suppliers, distributors and loyal competitors to promote fair trade; and designing schemes for modernization, innovation and technological development such as ecommerce. In conclusion, the performance of Tecamachalco's commercial businesses tends to be unsatisfactory and uncompetitive; the strategies designed could contribute to the competitiveness of the grocery stores.
\end{abstract}

Competition, Management, Strategies
Resumen

El objetivo fue diseñar estrategias y generar un plan de acción que contribuya a la competitividad de los establecimientos comerciales del municipio de Tecamachalco, Puebla. Los procedimientos realizados fueron: la revisión de documentación descriptiva y explicativa para la identificación de variables que se integraron a la encuesta, procesamiento de datos y construcción de índices, tablas y gráficos para analizar e interpretar las relaciones entre variables y generación de estrategias. Los resultados indican que, con respecto a la gestión de las empresas, el 63\% nunca define su filosofía organizacional, más de la mitad de ellos nunca aplica programas de calidad total y mejora continua, el $56 \%$ nunca se asocia para suministrar y distribuir sus productos y no recurre a productos externos. financiamiento, el $66 \%$ considera que el precio de su producto es adecuado para sus competidores y el $64 \%$ establece precios basados en su nivel de costos y ganancias, y el 64\% no utiliza técnicas de contabilidad y gestión, pero está dispuesto a recibir asesoramiento. Con respecto a los empleados, el 56\% de ellos tienen nociones elementales de las funciones y actividades que realizan, el $67 \%$ ocasionalmente ha recibido incentivos para el cumplimiento de los objetivos. Las estrategias diseñadas fueron: capacitación en cultura empresarial con procedimientos, prácticas y estándares que contribuyen a la calidad en los procesos de comercialización y servicio; integrando organizaciones que faciliten la obtención de financiamiento para la consolidación de negocios existentes; creando alianzas estratégicas con proveedores, distribuidores y competidores leales para promover el comercio justo; y el diseño de esquemas de modernización, innovación y desarrollo tecnológico como el comercio electrónico. En conclusión, el desempeño de los negocios comerciales de Tecamachalco tiende a ser insatisfactorio y poco competitivo; Las estrategias diseñadas podrían contribuir a la competitividad de los supermercados.

Competencia, Gestión, Estrategias

Citation: REZA-SALGADO, Juventino, GUERRERO-PAPAQUI, Roxana* and LÓPEZ-GONZÁLEZ, Patricia. Strategies for the competitiveness of the trade in Tecamachalco, Puebla: Case of the grocery stores. Journal of Business Development Strategies. 2019, 5-15: 27-34

\footnotetext{
* Correspondencia del Autor (correo electronico: j_gpapaqui@yahoo.com.mx)

$\dagger$ Investigador contribuyendo como primer autor.
} 


\section{Introduction}

Trade is an economic activity in which different goods and/or services are bought and sold. Moreover, it is fundamental to any economy, as it contributes to the efficient distribution of scarce resources among individuals or countries, allowing them to access goods that have been produced or processed at the lowest possible cost. Historically, the exchange of products of different kinds and between different communities and countries has been constant. However, currently, this process of buying and selling is carried out by legally established or informally operating organizations such as family businesses or establishments. In this sense, the literature records different conceptualizations about companies, businesses, or establishments as follows:

The company; defined by Nuño de León (2012) as the "economic-social unit whose purpose is to obtain a benefit or utility, both for the businessman and his organization and for the society in which he is immersed, where the capital, natural resources, work, and management are coordinated to satisfy market needs (Nuño de León, 2012: 11), with the action of coordinating being that which allows resources to be directed towards a common objective in all companies; to cover the expectations of their demand.

In Mexico, regarding the size of the company the same author says "as of June 30 , 2009 , the size is determined by the total number of staff of the organization and the level of annual sales" (Nuño de León, 2012: 11), on the other hand also in Mexico "three criteria are used to classify the company consisting of the number of employees, sales and a criterion in which the product of both values is valued" (Posada, 2016: 2) And it is based on this classification that micro and small enterprises are defined as: "micro-enterprises of any productive sector (industrial, commercial or service) are integrated by up to 10 workers and with an annual sales amount of up to four million pesos." (Nuño de León, 2012: 11), and on the second one, "small trade companies have 11 to 30 workers, with annual sales of four to one hundred million pesos." (Nuño de León, 2012: 12)
According to Maldonado (2017), "Micro businesses commonly specialize in the generation of a particular product or service and generally concentrate their efforts on the development of this product or service in too limited a commercial area, so that the benefits they obtain are seriously limited by their production capacity. (Maldonado, 2017) $\mathrm{He}$ adds... "the day-to-day business activities carried out by micro-enterprises in Mexico, as in any other Latin American country, are very limited in terms of human, technical and financial resources, and are usually a function of the knowledge, capacities, skills and experience that the managers and/or owners have. (Maldonado, 2017)

These companies carry out commercial acts from different types of activities.

The commercial companies are intermediaries between the producer and the consumer, being their primary function, the purchase, sale and/or distribution of products. (Nuño de León, 2012: 18)

Talking about the company... "Size conditions in a certain way how the activities of the organization are structured and developed, but, in the case of the micro and small company, the highest level of conditioning comes from the family itself." (Nuño de León, 2012: 14)

Some data indicate that "for Mexico, as mentioned by Gerardo Ruiz Mateos, Secretary of Economy in Mexico (2010), MSMEs represent for the nation $99.8 \%$ of the 4,007,100 economic units, $52 \%$ of Gross Domestic Product (GDP) and $72 \%$ of formal jobs, and are a potential for sustainable development of the nation, due to the management of gender equity, the reorganization of production that has as a characteristic of success its flexibility and its horizontal approach to structure; this will allow Mexico to incorporate more easily to globalization." (Nuño de León, 2012: 12)

Competitiveness, the fundamental concept around which this work revolves, "is not recent, it goes back to the mercantilist era, but specifically, it arises and spreads from the English term, and it comes from the concept competition which in turn means dispute or contest between two or more people over something (Berumen and Palacios, 2009), according to Porter 
"in the area of competitive advantage, the production of goods and services of higher quality and lower price than domestic and international competitors is considered to translate into increasing benefits for the inhabitants of a nation by maintaining and increasing real incomes (Porter, 1999).

In this process of exchange, small and medium-sized businesses face various problems that place them at a vital crossroads with two options: to modernize or to cease to exist, as an alternative would be to remain in the market. This situation described also occurs in the small commerce of Tecamachalco, Puebla, and according to data obtained from key informants, the following predominate:

The most outstanding problems it faces in the specific area are its individualism, anarchic isolation, and lack of knowledge about administrative aspects. Concerning consumers, the trader is unaware of the careful attention he must provide, the promotion of new consumers, and the change in purchasing habits. Likewise, he does not promote the consumer to choose his offer, the point of sale, and get their loyalty.

The economic and financial problems of small businesses are insufficient capital, low profitability, difficulties in obtaining the credit they need for expansion, modernization and equipment, and lack of coverage for all types of risks. Regarding the internal organization that must maintain the outlets lies in the lack of practical knowledge, from the advantageous use of local spaces (presentation and exhibition of the product) to the organizational forms, through the lack of management accounting system and management control.

The external aspects are the lack of minisector groups, the absence of exclusive federations for traders, the lack of professional protection and joint development policy, the lack of joint inter-professional actions with consumers, industrialists and the administration, and the lack of subsidies to promote the trader's professional training. Finally, lack of knowledge about how to deal with market competition, negotiation with suppliers and the legal system for microenterprises. Given the problems described above, we should ask ourselves, what are the internal and external conditions that do not allow the competitiveness of commercial microenterprises in Tecamachalco, Puebla?
Hypothesis 1: The lack of use of the tools of the administrative process does not allow the competitiveness of the commercial microenterprises in Tecamachalco, Puebla.Are there relevant actions that contribute to guaranteeing the competitive processes of small commercial outlets?

Hypothesis 2: Strategic planning allows for the design of strategies that contribute to the competitiveness of commercial microenterprises in Tecamachalco, Puebla. The objective was to design strategies and generate an action plan that contributes to the competitiveness of commercial establishments such as grocery stores in the municipality of Tecamachalco, Puebla.

\section{Methodology}

The work throughout its development was based on documentary and field information. The documentary research consisted of the following steps: identification of the problem in order to determine the objectives and hypotheses; research was done on the descriptive and explanatory documentation about the subject which allowed the identification of the variables to be investigated; finally, the questionnaire was designed to obtain the information and the sample size was calculated using the following formula:

$\mathrm{n}=\frac{N x Z_{a}^{2} Z x p x q}{d^{2} x(N-1)+Z_{a}^{2} x p x q}$

Where:

$\mathrm{N}=$ Population size

$\mathrm{Z}=$ Confidence level

$\mathrm{P}=$ Probability of success

$\mathrm{Q}=$ Probability of failure

$\mathrm{D}=$ Accuracy

Sample calculation:

$\mathrm{n}=\frac{(1.96)^{2}(2151)(.5)(.5)}{(.05)^{2}(2151-1)+(1.96)^{2}(.5)(.5)}=326.22$

In the fieldwork, we collected data through the application of the questionnaire; subsequently, the data obtained were processed in matrices to calculate indices and to produce tables and graphs. Based on the ordered, categorized information, handling and summary of the data, the relationships between the variables were analyzed and interpreted to arrive at conclusions linked to the objectives and hypotheses.

REZA-SALGADO, Juventino, GUERRERO-PAPAQUI, Roxana* and LÓPEZ-GONZÁLEZ, Patricia. Strategies for the competitiveness of the trade in Tecamachalco, Puebla: Case of the grocery stores. Journal of Business Development Strategies. 2019 


\section{Results}

The commercial activity of the municipality of Tecamachalco, Puebla, has been developed in a population that, according to INEGI data, in 2015 had 77061 inhabitants. Considering the population dynamics between 1990 and 2015, the population of the municipality increased annually by $2.26 \%$, that is, two people for every 100 inhabitants. In only 25 years, the population of the municipality was too close to double. From these data, it could be inferred that the activities of production and commercialization of goods and services have also had considerable growth.

However, this sustained growth has been uneven if we consider the performance of the trade of large establishments and small ones. The latter, according to the information obtained from the 327 surveys applied indicate, in general terms, that $60 \%$ of the management and customer service activities of microenterprises are carried out by the owner, to a lesser extent by the employees and minimally by the manager. The educational level of those who are engaged in trade is $54 \%$ of basic education, $41 \%$ upper secondary education, and only $5 \%$ of higher education. Concerning the organizational structure that could strengthen the competitiveness of commercial establishments, we present the following situation: $63 \%$ do not establish their mission, vision, objectives and values; the rest is divided between always, frequently, and sometimes (see graph 1).

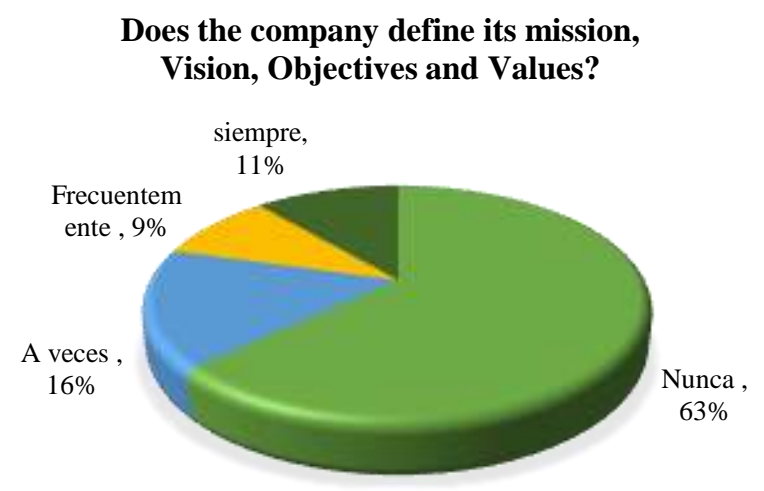

Graph 1 Definition of the philosophy

Source: (Prepared by the authors with data from the survey applied on April 14, 2017)
The microenterprises lack total quality and continuous improvement programs, since 53\% never apply them, the rest is distributed in the usual items, frequently and sometimes, around $15 \%$. (see graph 2 ).

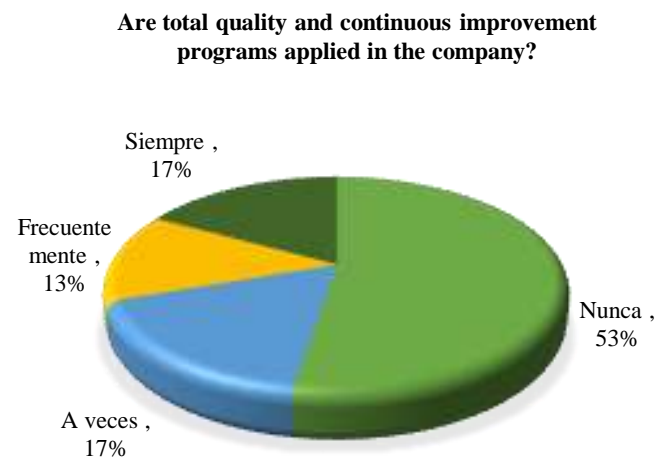

Graph 2 Quality and continuous improvement programs Source: (Prepared by the authors with data from the survey applied on April 14, 2017)

The right direction within the company, through the direct intervention of the person or persons who become managers, lies precisely in harmonizing the objectives that the company has set itself with those established by its employees if this is achieved it is one more element that would be contributing to raising productivity and therefore its competitiveness. However, the prevailing situation of commercial establishments is that about $47 \%$ of the management never motivate, nor do they manage to harmonize and make efficient the objectives of the company with those established by the employees, the rest of the percentage is distributed among always, sometimes and frequently. At the same time, $31 \%$ of employees are never informed of the functions to be performed, $25 \%$ sometimes, and $7 \%$ frequently, while $37 \%$ always. (see graph 3 ).

\section{Are the functions and activities of the position disclosed to each employee?}

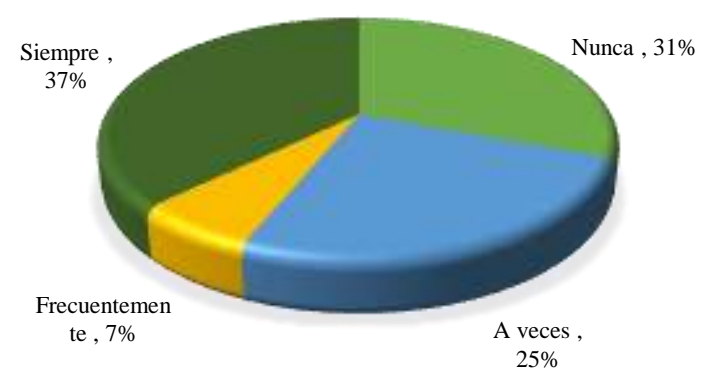

Figure 3 Job functions and activities

Source: (Prepared by the authors with data from the survey applied on April 14, 2017) 
The activity of integrating employee files is considered irrelevant and may not be necessary from the point of view of microenterprise management, since 55\% never carry out this activity and only 19\% do so always, the rest being distributed between sometimes and frequently.

$45 \%$ of the employees never receive incentives, but only $19 \%$ can always count on incentives, the rest being distributed between sometimes and frequently. (see graph 4).

Are incentives given to personnel for meeting objectives?

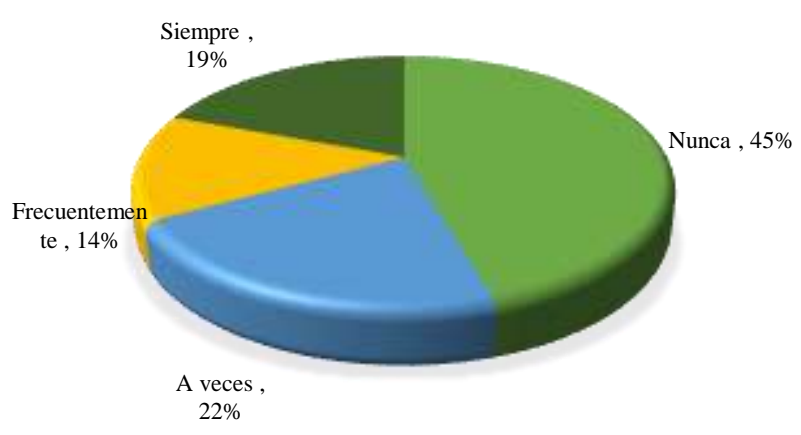

Graph 4 Staff incentives

Source: (Prepared by the authors with data from the survey applied on April 14, 2017)

In the market, companies of all kinds compete with each other to win over customers. So a greater or lesser market share is to some extent the result of the ratio of the cost of production to the prices at which the various goods or services are placed, and this occurs in an environment of closed competition between the various suppliers, with the quality or technology used as the basis for their advantageous position.

Therefore, the price at which the goods or services will be sold is of great importance for the company dedicated to trading. Taking into account these considerations, the companies or businesses of Tecamachalco, according to data provided by the survey, practically $66 \%$ believe that the price of their product is adequate in relation to that of their competitors, and therefore does not represent conflicts that lead to an open price war, and therefore, maintains an appropriate price in line with other competitors (see graph 5).

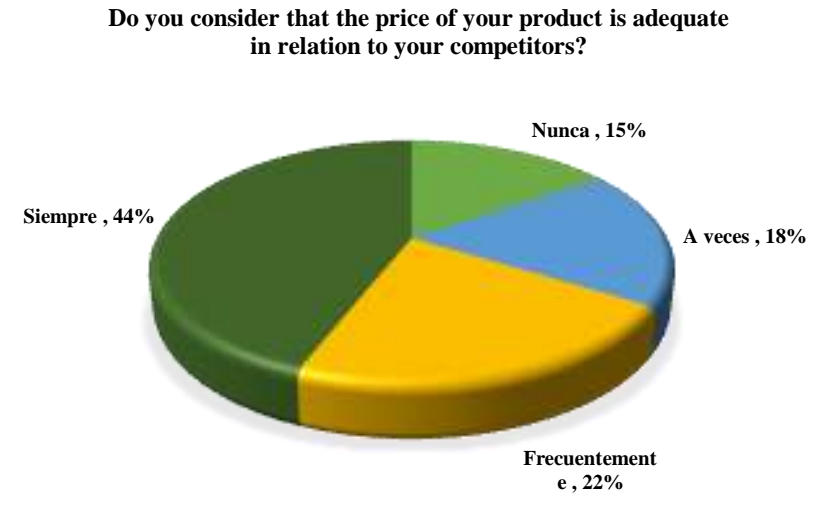

Graph 5 Product price

Source: (Prepared by the authors with data from the survey applied on April 14, 2017)

With regard to setting the prices of the products offered, practically $64 \%$ establish them based on their level of costs and profits, a process carried out in an empirical manner (see Graph 6).

\section{Is your pricing mechanism based on your level of cost and profit?}

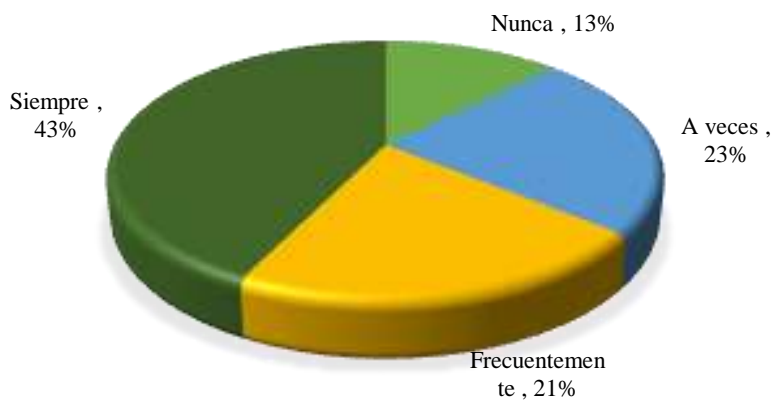

Graph 6 Pricing mechanisms

Source: (Prepared by the authors with data from the survey applied on April 14, 2017)

The process of consolidating and expanding the commercial coverage of products in the market requires the establishment of strategies that allow for taking advantage of the techniques and learnings of other companies that maintain control over broad sectors and that if alliances are promoted or partnerships are sought, success is guaranteed. However, what happens in the commercial sector of Tecamachalco is that more than half of the companies $(56 \%)$ never associate to carry out the supply and distribution of their products. Companies in general and commercial companies, in particular, need to improve their administrative processes and use the new tools that have recently been created to enable them to face their competitors successfully. This task is facilitated when those involved are willing to accept proposals for improvement. 
As is the case with commercial establishments since $66 \%$ are open to carrying out processes to improve administration in order to provide a better service to their customers. As for accounting and administrative control, $64 \%$ never or sporadically use the techniques derived from them. Thus, commercial microenterprises suffer from the lack of effective control of their movements of goods and monetary resources (see Graph 7).

According to the objectives of the company, do you manage an accounting and administrative control?

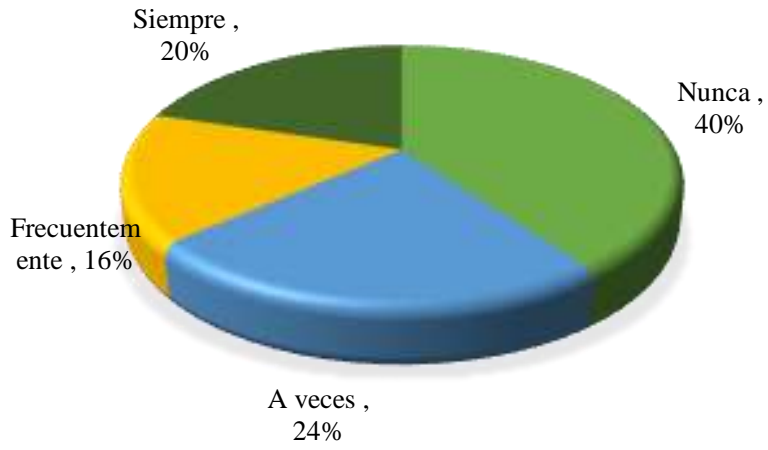

Graph 7 Accounting and administrative control Source: (Prepared by the authors with data from the survey applied on April 14, 2017)

The use of financing by companies is indispensable since it helps to strengthen their production processes, whether they are in the industrial, agricultural, or commercial sector. The latter, in the case of commercial establishments in the municipality of Tecamachalco, 64\% do not resort to external monetary resources (see graph). However, it is worth asking how microenterprises work in terms of financing. Possibly the most congruent answer is that the contributions come from the family or social capital that has been saved for a more or less long period by one or some of the family members or in a personal capacity. (see graph 8).

Is there a collection and payment system in place?

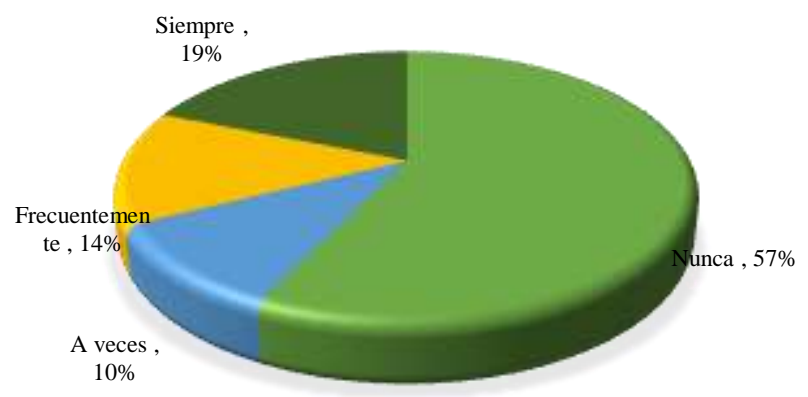

Graph 8 Collection and payment system

Source: (Prepared by the authors with data from the survey applied on April 14, 2017)

\section{Development of SWOT Analysis}

In order to analyze and generate strategies, we used the SWOT technique because it is mainly oriented towards the analysis and resolution of problems by identifying the Strengths and Weaknesses of the organization, as well as the Opportunities and Threats.

\section{SWOT Analysis}

\begin{tabular}{|c|c|}
\hline Strengths & Weaknesses \\
\hline $\begin{array}{l}\text { S1. Owners run most micro- } \\
\text { enterprises or businesses. } \\
\text { S2. There is an openness to carry out } \\
\text { processes of improvement of the } \\
\text { management } \\
\text { improvement } \\
\text { S3. The market where the products are } \\
\text { offered is Tecamachalco. } \\
\text { S4. There are reasonable expectations } \\
\text { regarding the future of the company. } \\
\text { S5. The owners motivate the } \\
\text { employees to achieve the objectives. } \\
\text { S6. The staff is hired by the plant. } \\
\text { S7. Incentives are given to staff for } \\
\text { meeting objectives. } \\
\text { S8. Prices are set similar to those of } \\
\text { the competition. } \\
\text { S9. A mechanism is in place to } \\
\text { determine prices based on the level of } \\
\text { costs } \\
\text { S10. New or better products are } \\
\text { acquired. } \\
\text { S11. No recourse to financing. } \\
\text { S12. Suppliers are local. } \\
\text { S13. Entrepreneurs react to the } \\
\text { activities of competitors. } \\
\text { S14. Conditions are considered to be } \\
\text { better than in } 2015\end{array}$ & $\begin{array}{l}\text { W1. Entrepreneurs have basic education } \\
\text { (primary and secondary) } \\
\text { W2. The administrative and accounting } \\
\text { knowledge of most of the owners of the } \\
\text { organizations is scarce. } \\
\text { W3. More than half of the organizations } \\
\text { never define their mission, vision, } \\
\text { objectives, and values (organizational } \\
\text { philosophy) } \\
\text { W4. Total quality and continuous } \\
\text { improvement programs for } \\
\text { microenterprises are not applied (53\%). } \\
\text { W5. Managers (50\%) fail to harmonize the } \\
\text { objectives of the enterprise with those of } \\
\text { the employees. } \\
\text { W6. Managers (47\%) never motivate their } \\
\text { subordinates for effective collaboration to } \\
\text { enable high standards of productivity. } \\
\text { W7. Employees are never or sometimes } \\
\text { informed of the functions and activities } \\
\text { they will have to perform during their } \\
\text { employment. } \\
\text { W8. There is no efficient organizational } \\
\text { communication } \\
\text { W9. } 55 \% \text { never produce the files of the } \\
\text { staff recruited/documentation } \\
\text { W10. Employees (45\%) do not receive } \\
\text { incentives. } \\
\text { W11. Prices of goods are set, based on } \\
\text { their level of costs and profits. (64\%) } \\
\text { W12. } 48 \% \text { never use accounting and } \\
\text { management techniques. } \\
\text { W13. The sources of internal financing are } \\
\text { thir own savings and family. } \\
\text { W14. They do not have a collection and } \\
\text { payment system } \\
\text { W15. There is a lack of effective control of } \\
\text { their movements of goods and monetary } \\
\text { resources. } \\
\text { W16. Entrepreneurs report difficulties } \\
\text { concerning capital, purchasing, marketing, } \\
\text { and technology. } \\
\text { W17. 39\% have never used advertising and } \\
\text { promotion to stimulate sales, despite } \\
\text { recognizing its benefits. }\end{array}$ \\
\hline Opportunities & Threats \\
\hline $\begin{array}{l}\text { O1. The administrative and } \\
\text { accounting services of third parties } \\
\text { may be used. } \\
\text { O2. The price of the product is } \\
\text { estimated to be adequate in relation to } \\
\text { that of the competitors ( } 66 \% \text { ) } \\
\text { O3. There is a need to acquire new and } \\
\text { better products in order to cover the } \\
\text { needs of its customers. } \\
\text { O4. There is an openness to carry out } \\
\text { management improvement processes } \\
\text { to provide a better service to its } \\
\text { customers. } \\
\text { O5. The micro-enterprises in the } \\
\text { municipality of Tecamachalco carry } \\
\text { out their commercial activities, } \\
\text { mainly in the city of Tecamachalco. } \\
\text { (90\%) } \\
\text { O6. The location of their commercial } \\
\text { organizations is appropriate, taking } \\
\text { into account their suppliers and } \\
\text { consumers. (92\%) } \\
\text { O7. The advantageous geographical } \\
\text { location of Tecamachalco, being } \\
\text { flanked by Puebla City and Tehuacan } \\
\text { and by the highway, Mexico City and } \\
\text { Veracruz. } \\
\text { O8. The location of its commercial } \\
\text { organizations is adequate if suppliers } \\
\text { and consumers are taken into account. }\end{array}$ & $\begin{array}{l}\text { T1. They never associate to carry out the } \\
\text { supply of their products. } \\
\text { T2. They never partner to carry out the } \\
\text { distribution of their products. } \\
\text { T3. They do not resort to external } \\
\text { monetary resources (external financing). } \\
\text { T4. Approximately } 10 \% \text { of the market is } \\
\text { located in the interior of the state, and there } \\
\text { are practically no markets in other states or } \\
\text { abroad. } \\
\text { T5. Less than } 50 \% \text { ensures customer } \\
\text { satisfaction through after-sales services. } \\
\text { T6. They have not received government } \\
\text { advice for their regularization. } \\
\text { T7. They do not have a civil protection } \\
\text { report, a land-use report, a sanitary license } \\
\text { or endorsements. }\end{array}$ \\
\hline
\end{tabular}




\section{SWOT or ASFM Matrix}

Once the SWOT Matrix was completed, the next stage consisted of carrying out the so-called Analytical Strategy Formation Matrix (ASFM), developing four types of strategies, as proposed by David (2008):

\begin{tabular}{|c|c|c|}
\hline ASFM Matrix & 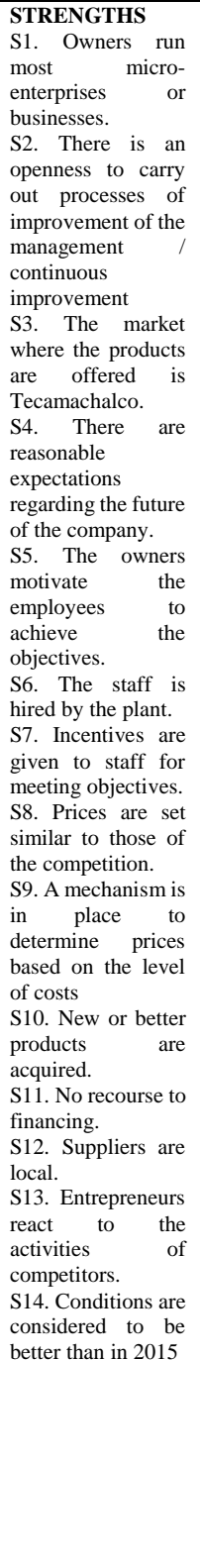 & $\begin{array}{l}\text { WEAKNESSES } \\
\text { W1. Entrepreneurs have basic } \\
\text { education (primary and } \\
\text { secondary) } \\
\text { W2. The administrative and } \\
\text { accounting knowledge of most } \\
\text { of the owners of the } \\
\text { organizations is scarce. } \\
\text { W3. More than half of the } \\
\text { organizations never define } \\
\text { their mission, vision, } \\
\text { objectives, and values } \\
\text { (organizational philosophy) } \\
\text { W4. Total quality and } \\
\text { continuous improvement } \\
\text { programs for microenterprises } \\
\text { are not applied (53\%). } \\
\text { W5. Managers } 50 \% \text { ) fail to } \\
\text { harmonize the objectives of } \\
\text { the enterprise with those of the } \\
\text { employees. } \\
\text { W6. Managers (47\%) never } \\
\text { motivate their subordinates for } \\
\text { effective collaboration to } \\
\text { enable high standards of } \\
\text { productivity. } \\
\text { W7. Employees are never or } \\
\text { sometimes informed of the } \\
\text { functions and activities they } \\
\text { will have to perform during } \\
\text { their employment. } \\
\text { W8. There is no efficient } \\
\text { organizational communication } \\
\text { W9. 55\% never produce the } \\
\text { files of the staff } \\
\text { recruited/documentation } \\
\text { W10. Employees ( } 45 \% \text { ) do not } \\
\text { receive incentives. } \\
\text { W11. Prices of goods are set, } \\
\text { based on their level of costs } \\
\text { and profits. (64\%) } \\
\text { W12. 48\% never use } \\
\text { accounting and management } \\
\text { techniques. } \\
\text { W13. The sources of internal } \\
\text { financing are their own } \\
\text { savings and family. } \\
\text { W14. They do not have a } \\
\text { collection and payment system } \\
\text { W15. There is a lack of } \\
\text { effective control of their } \\
\text { movements of goods and } \\
\text { monetary resources. } \\
\text { W16. Entrepreneurs report } \\
\text { difficulties concerning capital, } \\
\text { purchasing, marketing, and } \\
\text { technology. } \\
\text { W17. } 39 \% \text { have never used } \\
\text { advertising and promotion to } \\
\text { stimulate sales, despite } \\
\text { recognizing its benefits. }\end{array}$ \\
\hline $\begin{array}{l}\text { OPPORTUNITIES } \\
\text { O1. The administrative } \\
\text { and accounting services of } \\
\text { third parties may be used. } \\
\text { O2. The price of the } \\
\text { product is estimated to be } \\
\text { adequate in relation to that } \\
\text { of the competitors (66\%) } \\
\text { O3. There is a need to } \\
\text { acquire new and better } \\
\text { products in order to cover } \\
\text { the needs of its customers. } \\
\text { O4. There is an openness } \\
\text { to carry out management } \\
\text { improvement processes to } \\
\text { provide a better service to } \\
\text { its customers. } \\
\text { O5. The micro-enterprises } \\
\text { in the municipality of } \\
\text { Tecamachalco carry out } \\
\text { their } \\
\text { activities, commercial } \\
\text { city of Tecamachalco. } \\
\text { (90\%) } \\
\text { O6. The location of their } \\
\text { commercial organizations } \\
\text { is appropriate, taking into } \\
\text { account their suppliers } \\
\text { and consumers. (92\%) }\end{array}$ & $\begin{array}{l}\begin{array}{l}\text { SO strategies } \\
\text { (maxi-maxi) }\end{array} \\
\text { S1. Promote } \\
\text { sustainable trade } \\
\text { practices (S3, S8, } \\
\text { S10, S12, O3, O4, } \\
\text { O5, O6, O7, O8) }\end{array}$ & $\begin{array}{l}\text { OW strategies (mini-maxi) } \\
\text { S2. Provide training in } \\
\text { business culture with } \\
\text { procedures, practices and } \\
\text { standards that contribute to } \\
\text { quality in marketing and } \\
\text { service processes (W1, W2, } \\
\text { W12, W14, W15, W16, O1, } \\
\text { O4) }\end{array}$ \\
\hline
\end{tabular}

ISSN: 2444-4960

ECORFAN® All rights reserved

\begin{tabular}{|c|c|c|}
\hline $\begin{array}{l}\text { O7. The advantageous } \\
\text { geographical location of } \\
\text { Tecamachalco, being } \\
\text { flanked by Puebla City } \\
\text { and Tehuacán and by the } \\
\text { highway, Mexico City } \\
\text { and Veracruz. } \\
\text { O8. The location of its } \\
\text { commercial organizations } \\
\text { is adequate if suppliers } \\
\text { and consumers are taken } \\
\text { into account. }\end{array}$ & & \\
\hline $\begin{array}{l}\text { THREATS } \\
\text { T1. They never associate } \\
\text { to carry out the supply of } \\
\text { their products. } \\
\text { T2. They never partner to } \\
\text { carry out the distribution } \\
\text { of their products. } \\
\text { T3. They do not resort to } \\
\text { external monetary } \\
\text { resources (external } \\
\text { financing). } \\
\text { T4. Approximately 10\% } \\
\text { of the market is located in } \\
\text { the interior of the state, } \\
\text { and there are practically } \\
\text { no markets in other states } \\
\text { or abroad. } \\
\text { T5. Less than } 50 \% \\
\text { ensures customer } \\
\text { satisfaction through after- } \\
\text { sales services. } \\
\text { T6. They have not } \\
\text { received government } \\
\text { advice for their } \\
\text { regularization. } \\
\text { T7. They do not have a } \\
\text { civil protection report, a } \\
\text { land-use report, a sanitary } \\
\text { license or endorsements. }\end{array}$ & $\begin{array}{l}\begin{array}{l}\text { ST strategies } \\
\text { (maxi-mini) }\end{array} \\
\text { S3. Create strategic } \\
\text { alliances with } \\
\text { suppliers, } \\
\text { distributors and } \\
\text { loyal competitors } \\
\text { to promote fair } \\
\text { trade. (S2, S4, T1, } \\
\text { T2, T4) Design } \\
\text { E4. fomes for } \\
\text { schemes } \\
\text { modernization, and } \\
\text { innovation and } \\
\text { technological } \\
\text { development such } \\
\text { as e-commerce. } \\
\text { (S1, S2, S3, S4, T4, } \\
\text { T5) }\end{array}$ & $\begin{array}{l}\text { WT strategies (mini-mini) } \\
\text { S5. Integrate organizations } \\
\text { that facilitate obtaining } \\
\text { financing for the consolidation } \\
\text { of existing businesses. (W13, } \\
\text { T3) }\end{array}$ \\
\hline
\end{tabular}

In conclusion, the administrative process and its tools are not applied by small commercial establishments, which results in their performance being unsatisfactory and uncompetitive. Likewise, the application of strategic planning has allowed the design of strategies that contribute to the competitiveness of commercial microenterprises in Tecamachalco, Puebla.

The strategies designed: to promote sustainable trade practices, considering the advantage of location of businesses and suppliers in the region and adjacent states; to provide training in the business culture with procedures, practices, and standards that contribute to quality in the marketing and service processes; to create strategic alliances with suppliers, distributors, and loyal competitors to promote fair trade; to design schemes for modernization, innovation and technological development such as e-commerce; and to integrate organizations that facilitate obtaining financing for the consolidation of existing businesses, could contribute to the competitiveness of the grocery stores. For the implementation of the previously designed strategies, it is required the elaboration of action plans. 


\section{References}

Berumen, A. y O. Palacios, O. (2009). Competitividad, clusters e innovación. Mexico: Trillas S. A. de C.V.

Fred R., David (2008). Conceptos de administración estratégica. Mexico: Pearson Educación. INEGI (2015). Encuesta intercensal 2015. Recuperado de http: www.inegi.org.mx, 2017. Mexico

Maldonado, G. et al. (2017) La microempresa en México: un diagnóstico de su situación actual. Mexico

Nuño de León, P. (2012). Administración de pequeñas empresas. Mexico: Red Tercer Milenio

Porter, E., M. (1999). La ventaja competitiva de las naciones. Argentina: Javier Vergara, Buenos Aires. 